\title{
CORRESPONDENCE OPEN \\ Continued use of MDA-MB-435, a melanoma cell line, as a model for human breast cancer, even in year, 2014
}

npj Breast Cancer (2015) 1, 15002; doi:10.1038/npjbcancer.2015.2; published online 2 June 2015

It is a matter of significant concern, that the articles which refer MDA-MB-435 cell line as a breast cancer cell line are still being published in peer reviewed journals of international repute, even in 2014. Questions have been raised, for the last 14 years or so, about its origin and caution has been advised against using the cell line as a model for breast cancer. ${ }^{1-5}$ The origin of the cell line, notwithstanding few contradictory reports, ${ }^{6-8}$ has been established to be of melanoma.

The MDA-MB-435 cell line was originally derived from pleural effusion of a female breast cancer patient in 1976 at MDAnderson, Houston, TX, USA. Ever since the 'MDA-MB-435' cell line has been in use in established laboratories as a model for human breast cancer, worldwide. However, gene expression studies of melanoma and breast cancer, ${ }^{1,2} \mathrm{CpG}$ island promoter hypermethylation, ${ }^{3}$ SNP array investigation, ${ }^{9}$ and miRNA expression, ${ }^{10}$ have determined that the available MDA-MB-435 cells are of melanoma origin and not that of breast cancer. Further, Rae et al., ${ }^{4}$ in a more exhaustive study, employing whole battery of molecular techniques (karyotyping, comparative genomic hybridization, microsatellite polymorphic markers, bioinformatics analysis of SNP, and gene expression data) on the MDA-MB-435 cells obtained from repositories and various research laboratories, concluded that 'All currently available stocks of MDA-MB-435 cells are derived from M14 melanoma cell line', implying the usage of the cell line as a model for breast cancer as erroneous. These studies, unquestionably determined that the currently available MDA-MB-435 cells are not the original MDA-MB-435 cells obtained from the breast cancer patient but are misidentified M14 melanoma cells, and the original stock of MDA-MB-435 breast cancer cells were lost. ${ }^{4,5,11}$ Consequently, The American Type Culture Collection (ATCC, http:// www.atcc.org) and The German Collection of Microorganisms and Cell Cultures (DSMZ, http://www.dsmz.de) characterized the cells and reclassified them as melanoma cells, sometime in 2012. Corrections were also made on the websites of other cell repositories (European Collection of Cell Cultures (ECACC, http:// www.hpacultures.org.uk/collections/ecacc.jsp), The Japanese Collection of Research Bioresources (JCRB, http://cellbank.nibio.go.jp), and RIKEN Bioresource Center Cell Bank (RIKEN, http://www.brc. riken.go.jp/lab/cell/english/guide.shtml)).

However, a quick Pubmed search revealed that 36 research studies that mistakenly used the MDA-MB-435 cell line as a model for breast cancer are published in international peer reviewed journals, such as: Nature Cell Biology, ${ }^{12}$ Nature Communications, ${ }^{13}$ Journal of Experimental and Clinical Cancer Research ${ }^{14}$ Cell Death and Disease, ${ }^{15}$ PLoS One, ${ }^{16}$ Molecular Oncology, ${ }^{17}$ Archives of Pharmacal Research, ${ }^{18}$ Acta Pharmaceutica, ${ }^{19}$ Tumor Biology, ${ }^{20}$ Journal of Molecular Medicine (Berl) ${ }^{21}$ etc., even in 2014. The search also revealed publication of 247 such articles between 1 January 2008 and 12 December 2014, even after the MDA-MB-435 cell line was declared to be a melanoma cell line, in 2007. A total of 890 published studies have used the cell line as a model for human breast cancer till date (Pubmed, 12 December 2014). Some of the notable studies of recent past have used the MDA-MB-435 cells for investigating: (i) anti-proliferative effect of 2-methoxyestradiol which is in phase I/II clinical trials for treating breast cancer, ${ }^{22}$ (ii) effect of herceptin on the breast cancer cells, using MDA-MB-435, ${ }^{23}$ (iii) EphB6 receptor effect on invasiveness of human breast carcinoma cells, ${ }^{24}$ (iv) a protein target for immunotherapy of triple-negative breast cancer, ${ }^{25}$ and (v) antiPTHrP antibody mediated enhancement of anti-proliferation ability of cancer drugs, ${ }^{26}$ which is now established to be a melanoma cell line. Such a continued mistaken use and acceptance of such articles for publication in scientific journals adds to the confusion and the questionable data generated using inappropriate models continue to populate cancer research data bases, used by academicians, researchers and pharmacologists.

In addition to the MDA-MB-435 cell line, various other nonbreast cancer cell lines are also being used to study breast cancer. ${ }^{27}$ By year 1999 itself, 45 cell lines were reported to be cross contaminated by the originators. ${ }^{28}$ Since then, the list of the crosscontaminated/misidentified cell lines has grown substantially, as indicated by the list on the Database of Cross Contaminated or Misidentified Cell lines. ${ }^{29}$ Nevertheless, employing mischaracterized/misidentified cell lines to study human diseases, particularly cancer, cannot be sporadic and publishing such misleading data should and must be contained. Continued dissemination of faulty data through publications, inspite of few initiatives taken up by certain journals (Breast Cancer Research, Cancer Research, PNAS etc.,) to discontinue the usage of unauthentic/misidentified cell lines indicates a lack of concerted effort and underscores the need for a cohesive, coordinated and comprehensive approach as opposed to isolated steps by few journals.

In view of the widespread use of cell lines in understanding physiological pathways and pathophysiology of human diseases, we call upon the editors of the concerned journals to form a consortium along with the major cell depositories, funding agencies, and cancer researchers across the globe. The consortium can undertake the task of re-characterizing/re-classifying and establishing the true origin of the cells, once for all, taking advantage of the latest molecular biology, proteomics and metabolomics techniques and bioinformatics tools. Once the identity of the cell lines is determined conclusively and the cell lines are re-classified, appropriate guidelines may be framed and publicized. Although, such task is onerous, bringing such awareness about the validity of the cell lines will be of importance and make a significant contribution to cancer research. In the meanwhile, it may be incumbent on the Journals, to stop accepting studies that have used incorrect cell line model to investigate a disease and to compile a list of published studies that have used wrong cell lines to study disease, and circulate and publicize the list widely.

\section{ACKNOWLEDGMENTS}

We would like to acknowledge the editorial help rendered by Dr Saritha Katta, $R \& D$, $B I A C H \& R I$.

\section{COMPETING INTERESTS}

The authors declare no conflict of interest. 
Vidudala VTS Prasad ${ }^{1}$ and Ramprasad OG Gopalan ${ }^{1}$

${ }^{1}$ Research and Development, Basavatarakam Indo-American Cancer Hospital and Research Institute, Hyderabad, India Correspondence: VVTS Prasad (vidudalap@yahoo.com)

\section{REFERENCES}

1 Ross DT, Scherf U, Eisen MB, Perou CM, Rees C, Spellman P et al. Systematic variation in gene expression patterns in human cancer cell lines. Nat Genet 2000; 24: 227-235.

2 Ellison G, Klinowska T, Westwood RF, Docter E, French T, Fox JC. Further evidence to support the melanocytic origin of MDA-MB-435. Mol Pathol 2002; 55: 294-299.

3 Paz MF, Fraga MF, Avila S, Guo M, Pollan M, Herman JG et al. A systematic profile of DNA methylation in human cancer cell lines. Cancer Res 2003; 63: 1114-1121.

4 Rae JM, Creighton CJ, Meck JM, Haddad BR, Johnson MD. MDA-MB-435 cells are derived from M14 melanoma cells--a loss for breast cancer, but a boon for melanoma research. Breast Cancer Res Treat 2007; 104: 13-19.

5 Holliday DL, Speirs V. Choosing the right cell line for breast cancer research. Breast Cancer Res 2011; 13: 215.

6 Sellappan S, Grijalva R, Zhou X, Yang W, Eli MB, Mills GB et al. Lineage infidelity of MDA-MB-435 cells: expression of melanocyte proteins in a breast cancer cell line. Cancer Res 2004; 64: 3479-3485.

7 Chambers AF. MDA-MB-435 and M14 cell lines. Identical but not M14 melanoma. Cancer Res 2009; 69: 5292-5293.

8 Zhang Q, Fan H, Shen J, Hoffman RM, Xing HR. Human breast cancer cell lines coexpress neuronal, epithelial and melanocytic differentiation markers in vitro and in vivo. PLoS One 2010; 5: e9712.

9 Garraway LA, Widlund HR, Rubin MA, Getz G, Berger AJ, Ramaswamy S et al. Integrative genomic analyses identify MITF as a lineage survival oncogene amplified in malignant melanoma. Nature 2005; 436: 117-122.

10 Gaur A, Jewell DA, Liang Y, Ridzon D, Moore JH, Chen C et al. Characterization of microRNA expression levels and their biological correlates in human cancer cell lines. Cancer Res 2007; 67: 2456-2468.

11 Rae JM, Ramus SJ, Waltham M, Armes JE, Campbell IG, Clarke R et al. Common origins of MDA-MB-435 cells from various sources with those shown to have melanoma properties. Clin Exp Metastasis 2004; 21: 543-552.

12 Lu H, Clauser KR, Tam WL, Frose J, Ye X, Eaton EN et al. A breast cancer stem cell niche supported by juxtacrine signalling from monocytes and macrophages. Nat Cell Biol 2014; 16: 1105-1117.

13 Wang W, Qin JJ, Voruganti S, Srivenugopal KS, Nag S, Patil S et al. The pyrido[b] indole MDM2 inhibitor SP-141 exerts potent therapeutic effects in breast cancer models. Nat Commun 2014; 5: 5086.

14 Li J, Liu J, Yang J, Li P, Mao X, Li W et al. Loss of LKB1 disrupts breast epithelial cell polarity and promotes breast cancer metastasis and invasion. J Exp Clin Cancer Res 2014; 33: 70

15 Hou P, Zhao Y, Li Z, Yao R, Ma M, Gao Y et al. LincRNA-ROR induces epithelial-tomesenchymal transition and contributes to breast cancer tumorigenesis and metastasis. Cell Death Dis 2014; 5: e1287.
16 Jiao F, Bai SY, Ma Y, Yan ZH, Yue Z, Yu Y et al. DNA methylation of heparanase promoter influences its expression and associated with the progression of human breast cancer. PLoS One 2014; 9: e92190.

17 Marcato P, Dean CA, Liu RZ, Coyle KM, Bydoun M, Wallace M et al. Aldehyde dehydrogenase $1 \mathrm{~A} 3$ influences breast cancer progression via differential retinoic acid signaling. Mol Oncol 2015; 9: 17-31.

$18 \mathrm{Yoo} \mathrm{H}$, Mok H. Evaluation of multimeric siRNA conjugates for efficient protaminebased delivery into breast cancer cells. Arch Pharm Res 2015; 38: 129-136.

19 Abdou WM, Ganoub NA, Sabry E. Design, synthesis and pharmacological screening of beta-amino-, thiadiazole/thiadiazine-phosphonate based triazole motifs as antimicrobial/cytotoxic agents. Acta Pharm 2014; 64: 267-284.

20 Jia J, Yang M, Chen Y, Yuan H, Li J, Cui X et al. Inducing apoptosis effect of caffeic acid 3,4-dihydroxy-phenethyl ester on the breast cancer cells. Tumour Biol 2014; 35: 11781-11789.

21 Xiang L, Gilkes DM, Chaturvedi P, Luo W, Hu H, Takano N et al. Ganetespib blocks HIF-1 activity and inhibits tumor growth, vascularization, stem cell maintenance, invasion, and metastasis in orthotopic mouse models of triple-negative breast cancer. J Mol Med (Berl) 2014; 92: 151-164.

22 Bhati R, Gokmen-Polar Y, Sledge GW Jr., Fan C, Nakshatri H, Ketelsen D et al. 2methoxyestradiol inhibits the anaphase-promoting complex and protein translation in human breast cancer cells. Cancer Res 2007; 67: 702-708.

23 Spankuch B, Kurunci-Csacsko E, Kaufmann M, Strebhardt K. Rational combinations of siRNAs targeting Plk1 with breast cancer drugs. Oncogene 2007; 26: 5793-5807.

24 Fox BP, Kandpal RP. EphB6 receptor significantly alters invasiveness and other phenotypic characteristics of human breast carcinoma cells. Oncogene 2009; 28: 1706-1713.

25 Wang X, Osada T, Wang Y, Yu L, Sakakura K, Katayama A et al. CSPG4 protein as a new target for the antibody-based immunotherapy of triple-negative breast cancer. J Natl Cancer Inst 2010; 102: 1496-1512.

26 Camirand A, Fadhil I, Luco AL, Ochietti B, Kremer RB. Enhancement of taxol, dox orubicin and zoledronate anti-proliferation action on triple-negative breast cancer cells by a PTHrP blocking monoclonal antibody. Am J Cancer Res 2013; 3: 500-508.

27 Christgen M, Lehmann U. MDA-MB-435: the questionable use of a melanoma cell line as a model for human breast cancer is ongoing. Cancer Biol Ther 2007; 6: 1355-1357.

28 MacLeod RA, Dirks WG, Matsuo Y, Kaufmann M, Milch H, Drexler HG. Widespread intraspecies cross-contamination of human tumor cell lines arising at source. Int $J$ Cancer 1999; 83: 555-563.

29 International Cell Line Authentication Committee (ICLAC)Database of cross contaminated or misidentified cell lines http://www.dsmz.de/fileadmin/Bereiche/ HumanandAnimalCellLines/Cross_Contaminations_v7_1.pdf22 August 2013.

This work is licensed under a Creative Commons Attributioncc) NonCommercial-NoDerivatives 4.0 International License. The images or other third party material in this article are included in the article's Creative Commons license, unless indicated otherwise in the credit line; if the material is not included under the Creative Commons license, users will need to obtain permission from the license holder to reproduce the material. To view a copy of this license, visit http:// creativecommons.org/licenses/by-nc-nd/4.0/ 